\title{
Floating iris cyst mimicking intravitreal cysticercosis
}

\author{
Parijat Chandra, Anil Gangawe, Deepali Singhal, Atul Kumar
}

Dr R P Centre for Ophthalmic Sciences, All India Institute of Medical Sciences (AlIMS), New Delhi, India

\section{Correspondence to} Dr Parijat Chandra, parijatchandra@gmail.com

Accepted 28 November 2015

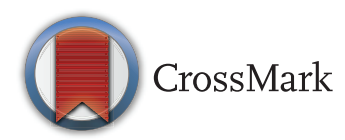

To cite: Chandra $P$, Gangawe A, Singhal D, et al. BMJ Case Rep Published online: [please include Day Month Year] doi:10.1136/bcr-2015213484

\section{DESCRIPTION}

A 12-year-old girl presented with a history of repeated headaches (with no ocular symptoms) for 3 years. There was no history of ocular trauma or surgery. On ocular examination elsewhere, she was diagnosed as having intravitreal cysticercosis after observing a cyst in the left eye and was referred for vitrectomy to a tertiary eye care centre.

Her vision was 20/20 in both eyes, with no signs of ocular inflammation. Biomicroscopic examination of the left eye showed a mobile, pigmented, circular cyst in the anterior vitreous, but it was not blocking the pupillary axis (figure 1). Intraocular pressure and fundus examination of both eyes was normal. Ultrasonography revealed a free-floating cyst with no scolex in the anterior vitreous. Ultrasound biomicroscopy did not show any other cyst or mass in the iris and ciliary body. Non-contrast head CT of the brain and orbit ruled out intracranial cysticercosis. The headaches were attributed to convergence insufficiency and the patient was advised orthoptic exercises.

It is easy for a floating iris cyst to mimic intraocular cysticercosis, as it is a common diagnosis, and

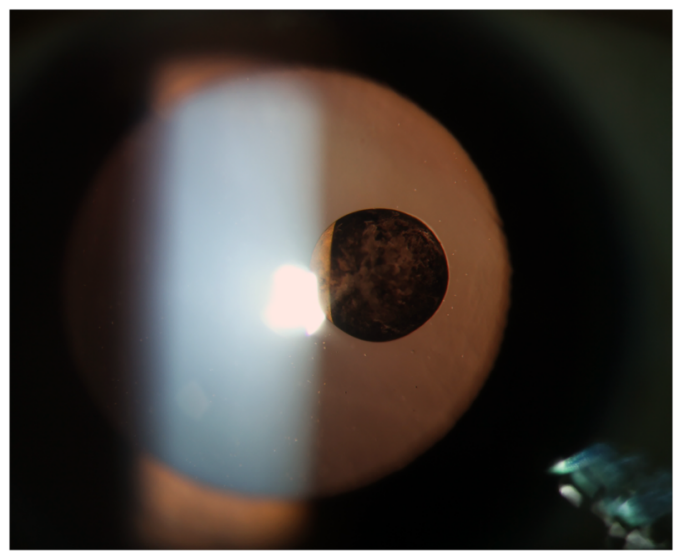

Figure 1 Slit-lamp retroillumination showing a free-floating pigmented iris cyst in the anterior vitreous in the left eye. also, most surgeons are unaware about iris cysts. Often, neuroimaging is normal and adds to the diagnostic dilemma. Although both appear quite similar, the classic pigmentation on the cyst wall, lack of ocular inflammation and lack of scolex on USG help confirm diagnosis of the floating iris cyst.

Shield ${ }^{1}$ postulated that epithelial cysts arise between the pigmented epithelial layers of the iris, and often break free and migrate into the vitreous chamber, and these are called dislodged cysts. Lois et $a l^{2}$ reported that $12 \%$ of primary iris pigment epithelium cysts were vitreous cysts. Sugar $e t a l^{3}$ suggest it is important to distinguish retrolental iris cysts (between lens and anterior hyaloid) from anterior vitreous cysts-as retrolental cysts may cause visual disturbance and may be associated with posterior lenticular opacities.

\section{Learning points}

- Free-floating iris cysts in the vitreous are uncommon, yet they are commonly confused with more serious conditions, but require no treatment.

- In the differential diagnosis of any intraocular cyst, a high index of suspicion should be kept for benign dislodged iris cysts.

Competing interests None declared.

Patient consent Obtained.

Provenance and peer review Not commissioned; externally peer reviewed.

\section{REFERENCES}

1 Shields JA. Primary cysts of the iris. Trans Am Ophthalmol Soc 1981;79:771-809.

2 Lois N, Shields CL, Shields JA, et al. Primary cysts of the iris pigment epithelium. Clinical features and natural course in 234 patients. Ophthalmology 1998;105:1879-85.

3 Sugar HS, Bogord D, Richards BW. Free floating cyst of the retrolental space. Arch Ophthalmol 1990;108:483-4.

Copyright 2015 BMJ Publishing Group. All rights reserved. For permission to reuse any of this content visit http://group.bmj.com/group/rights-licensing/permissions.

BMJ Case Report Fellows may re-use this article for personal use and teaching without any further permission.

Become a Fellow of BMJ Case Reports today and you can:

- Submit as many cases as you like

- Enjoy fast sympathetic peer review and rapid publication of accepted articles

- Access all the published articles

- Re-use any of the published material for personal use and teaching without further permission

For information on Institutional Fellowships contact consortiasales@bmjgroup.com

Visit casereports.bmj.com for more articles like this and to become a Fellow 